\title{
Occurrence of Five Different Orthogonal Smectic Phases in a Bent-Core (BC) Liquid Crystal
}

\author{
S. Sreenilayam \\ Trinity College Dublin, Ireland \\ Yuri Panarin \\ Technological University Dublin, yuri.panarin@tudublin.ie \\ J. K. Vij \\ Trinity College Dublin, Ireland, jvjj@tcd.ie
}

See next page for additional authors

Follow this and additional works at: https://arrow.tudublin.ie/engscheleart2

Part of the Electrical and Computer Engineering Commons

\section{Recommended Citation}

Lehmann, A. et al. (2015). Occurrence of five different orthogonal smectic phase in a bent-core (BC) liquid crystal. Molecular Crystals and Liquid Crystals, vol. 610, pp. 116-121. DOI:10.1080/

15421406.2015.1025606

This Article is brought to you for free and open access by the School of Electrical and Electronic Engineering at ARROW@TU Dublin. It has been accepted for inclusion in Articles by an authorized administrator of ARROW@TU Dublin. For more information, please contact arrow.admin@tudublin.ie, aisling.coyne@tudublin.ie, gerard.connolly@tudublin.ie.

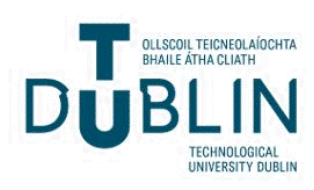




\section{Authors}

S. Sreenilayam, Yuri Panarin, J. K. Vij, A. Lehmann, and C. Tschierske

This article is available at ARROW@TU Dublin: https://arrow.tudublin.ie/engscheleart2/157 


\title{
Occurrence of Five Different Orthogonal Smectic Phases in a Bent-Core (BC) Liquid Crystal
}

\author{
S. SREENILAYAM, ${ }^{1}$ YU. P. PANARIN,${ }^{1,2, *}$ J. K. VIJ, ${ }^{1, *}$ \\ A. LEHMANN, ${ }^{3}$ AND C. TSCHIERSKE ${ }^{3}$ \\ ${ }^{1}$ Department of Electronic and Electrical Engineering, Trinity College, \\ University of Dublin, Dublin, Ireland \\ ${ }^{2}$ School of Electronic \& Communication Engineering, Dublin Institute of \\ Technology, Dublin, Ireland \\ ${ }^{3}$ Institute of Chemistry, Organic Chemistry, Martin-Luther-University \\ Halle-Wittenberg, Germany
}

\begin{abstract}
Five orthogonal smectic phases ( $S m-\mathrm{A}, S m-\mathrm{A}_{\mathrm{b}}, S m-\mathrm{AP}_{\mathrm{R}}, S m-\mathrm{AP}_{\mathrm{AR}}$, and $S m-\mathrm{AP}_{\mathrm{A}}$ ) were observed in a 4-cyanoresorcinol bisbenzoate with two terephthalate-based wings achiral bent-core (BC) compound. The phase behavior was investigated by polarising optical microscopy, second harmonic electro-optic response $\left(\mathrm{EO}_{2}\right)$ and dielectric spectroscopy. The field dependent biaxiality of polar and non-polar Sm-A phases was studied. It is obviously of enormous scientific significance and practical interest to find five different orthogonal smectic phases in a low molecular weight bent-core (BC) compound at relatively low temperatures.
\end{abstract}

Keywords bent-core molecule; orthogonal Smectic; electro-optic effects; dielectric relaxation

\section{Introduction}

A considerable interest has been shown by the liquid crystalline community in the study of ferroelectricity and antiferroelectricity in liquid crystalline (LC) materials composed of achiral molecules [1-3]. In 1992, Brand et al. introduced a model of ferroelectricity for an orthogonal smectic phase $(C P)$ formed by non-chiral bent-core $(\mathrm{BC})$ molecules [4] and Niori et al. reported the first experimental evidence of ferroelectricity in 1996 [5].

Recently, many orthogonal smectics composed of BC, LC molecules showing different phase structures and phase transitions have been synthesized and investigated with a large shape biaxiality and strong polarity [6-9]. Some of the studies in this direction include an investigation of orthogonal polar smectic mesophases such as Sm- $A P_{A}$ [10-13], Sm$A P_{R}[14,15]$ and $\mathrm{Sm}-A P_{A R}[16]$. In all these achiral $\mathrm{Sm}-A$ phases, the molecular rotation

*Address correspondence to Yu. P. Panarin and J. K. Vij, Department of Electronic and Electrical Engineering, Trinity College, University of Dublin, Dublin 2, Ireland. E-mail: yuri.panarin@ dit.ie; jvij@tcd.ie

Color versions of one or more of the figures in the article can be found online at www.tandfonline.com/gmcl. 


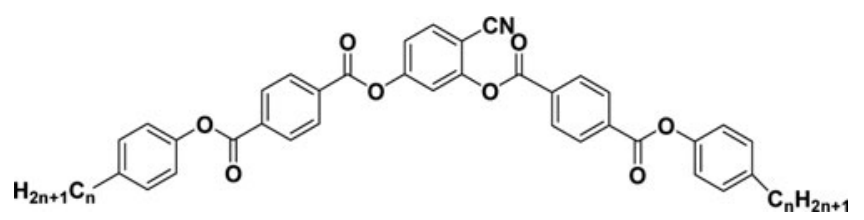

Figure 1. Molecular structure of the bent core LC compound with chain length $n=16$

around its principal axis within a smectic layer at least to some extent is biased. Hence, the molecules are packed in the $\mathrm{BC}$ direction which is also the polar-axis direction in a single layer. In Sm- $A P_{R}$ phase, the polarization direction from layer to layer is randomized leading to the macroscopic non-birefringent texture under crossed polarizers and in Sm$A P_{A}$ phase, the polarization direction between the adjacent layers are anti-parallel leading to an antiferroelectric phase which is biaxial. Ferroelectric phase $\left(\mathrm{Sm}-A P_{F}\right)$ with polarization direction in adjacent layers parallel to each other has also been observed [17]. The existence of non-polar biaxial Sm- $A_{b}$ phase or $C_{M}$ (McMillan) first suggested by de Gennes [1] was recently observed in LCs built from the non-symmetrical BC molecules and in their mixtures with calamitic molecules $[18,19]$.

Here we report a new $\mathrm{BC}$ material with symmetric terminal chain lengths which exhibits a phase sequence of three different polar orthogonal smectic phases $\left(\mathrm{Sm}-A P_{A}, \mathrm{Sm}-A P_{A R}\right.$ and $\mathrm{Sm}-A P_{R}$ ) in addition to optically biaxial non-polar $\mathrm{Sm}-A_{b}$ on cooling down from the optically uniaxial $\mathrm{Sm}-A$. Occurrence of these phases was confirmed by biaxiality measurements [20-23], second harmonic electro-optic response [23] and dielectric spectroscopy [24]. It is obviously of enormous to significance to find the five different mesophases at relatively lower temperature region in a low molar pure BC compound having a highly polar cyano group attached to the middle of the core.

\section{Experiments}

The smectic BC compound under study, 4-cyanoresorcinol bisbenzoate with two terephthalate-based wings was synthesized in Halle Germany. The molecular structure along with the phase transition temperatures and phase sequences are shown in Fig. 1. The material under investigation has symmetric terminal alkyl chains on both sides with the number of carbon atoms 16 (chain length $=16$ ). It exhibits the following phase sequence: $\mathrm{Cr} 75^{\circ} \mathrm{C}-\mathrm{Sm}-A P_{A} 90^{\circ} \mathrm{C}-\mathrm{Sm}-A P_{A R} 98^{\circ} \mathrm{C}-\mathrm{Sm}-A P_{R} 107^{\circ} \mathrm{C}-\mathrm{Sm}-A_{b} 125^{\circ} \mathrm{C}-\mathrm{Sm}-A 164^{\circ} \mathrm{C}-\mathrm{I}$ on cooling from the isotropic temperature and $\mathrm{Cr} 110^{\circ} \mathrm{C}-\mathrm{Sm}-A_{b} 125^{\circ} \mathrm{C}-\mathrm{Sm}-A 162^{\circ} \mathrm{C}$-I, on heating from the crystalline state. It is interesting to note that the homologue series with very similar molecular structure, with $\mathrm{C}=\mathrm{O}$ bonds pointed in the same direction, exhibit only nematic phases [25].

For electro-optic measurements homeotropic alignment is obtained by two glass substrate coated with polymer AL60702 (JSR Korea). The electrodes are arranged with a separation of $\sim 80 \mu \mathrm{m}$ for applying the in-plane electric field at a frequency of $110 \mathrm{~Hz}$ by etching indium tin oxide (ITO) stripes on the bottom glass substrate. The dielectric study is carried out using broadband high resolution dielectric spectrometer (Novo control $\mathrm{GmbH}$, Germany) on planar (homogenous) cells. Homogeneous cell configuration was obtained by coating with polymer RN 1175 (Nissan chemicals, Japan). Sample thickness is adjusted using appropriate spacers and interference technique is used to measure the cell thickness. 


\section{Results and Discussions}

\subsection{Biaxiality Measurements}

Biaxiality measurements were performed using a tilting optical compensator. The effect of applied field on different Sm- $A$ phases was studied in a $5.5 \mu \mathrm{m}$ homeotropic cell under crossed polarizers with an angle of $45^{\circ}$ between the electric field and the polarizer axes. Magnitude of biaxiality measured as a function of voltage for different phases with a reduction in temperature is shown in Fig. 2.

On cooling the cell from the optically uniaxial Sm- $A$ to $125^{\circ} \mathrm{C}$, it first transforms to an optically biaxial $\mathrm{Sm}-A_{b}$ phase. By the application of electric field $(0.4 \mathrm{~V} / \mu \mathrm{m})$ the initial low-biaxiality $\left(\delta n=1.61 \times 10^{-4}\right)$ with a Schlieren texture becomes ordered and on a further increase in the field $(8.75 \mathrm{~V} / \mu \mathrm{m})$ the magnitude of biaxiality increases to $\delta n=0.0094$ at $118^{\circ} \mathrm{C}$. On further cooling this optically biaxial phase $\left(\mathrm{Sm}-A_{b}\right)$ turns to optically uniaxial $\mathrm{Sm}-A P_{R}$ phase at $107^{\circ} \mathrm{C}$. The initial uniaxial state goes to biaxial state $(\delta n=0.0056)$ only at a higher field $(8.75 \mathrm{~V} / \mu \mathrm{m})$. It shows an increasing trend of biaxiality by the application of higher electric field. The device containing the sample turns to Sm- $A P_{A R}$ phase at $98^{\circ} \mathrm{C}$, the macroscopically uniaxial state $(\delta n=0)$ goes to biaxial antiferroelectric state $(\delta n=0.0019$ at $1.5 \mathrm{~V} / \mu \mathrm{m})$ and then to ferroelectric ordered saturated state $(\delta n=0.0140$, at $6.25 \mathrm{~V} / \mu \mathrm{m})$ through uniaxial order $(\delta n=0$ at $2.75 \mathrm{~V} / \mu \mathrm{m})$. At $90^{\circ} \mathrm{C}$, the initial Schliren texture of $\mathrm{Sm}-A P_{A}$ phase $(\delta n=0.0026$, at $0 \mathrm{~V} / \mu \mathrm{m})$ goes to the ordered biaxial antiferroelectric structure $(\delta \boldsymbol{n}=0.0073$, at $1.25 \mathrm{~V} / \mu \mathrm{m})$ and on further application of field; it turns to ordered ferroelectric saturated state $(\delta n=0.0168$, at $5.25 \mathrm{~V} / \mu \mathrm{m})$ through an optically uniaxial state $(\delta n=0$, at $3.5 \mathrm{~V} / \mu \mathrm{m})$. At a particular temperature $\left(78^{\circ} \mathrm{C}\right), \delta n$ value of both antiferroelectric and ferroelectric states are similar. From Fig. 2 it is clearly seen that the magnitude of field dependent biaxiality of all smectic phases gradually increases with a reduction in temperature.

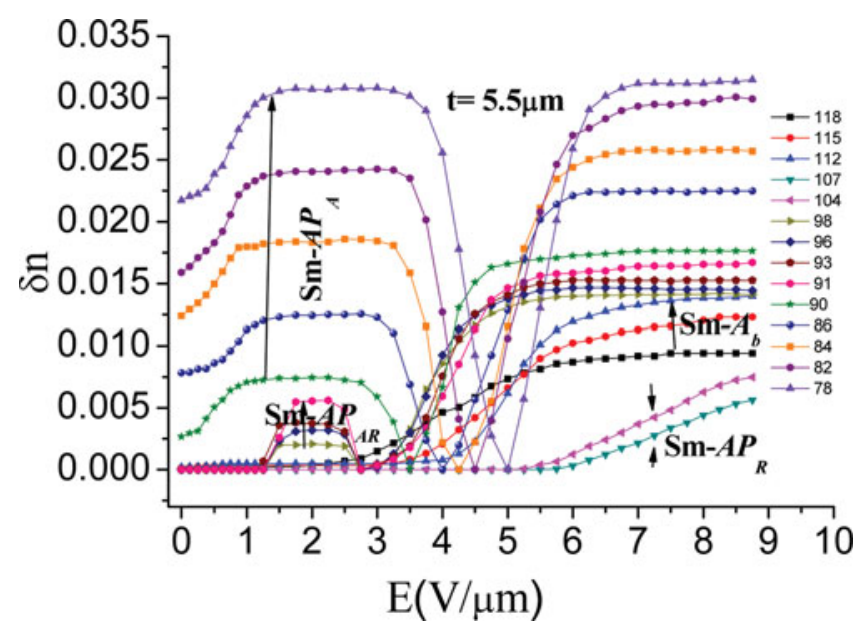

Figure 2. The field dependent biaxiality measurement of orthogonal smectic LC phases, Sm- $A_{b}$ $\left(118^{\circ} \mathrm{C}-112^{\circ} \mathrm{C}\right), \mathrm{Sm}-A P_{R}\left(106^{\circ} \mathrm{C}-103^{\circ} \mathrm{C}\right), \mathrm{Sm}-A P_{A R}\left(100^{\circ} \mathrm{C}-91^{\circ} \mathrm{C}\right)$ and $\mathrm{Sm}-A P_{A}\left(88^{\circ} \mathrm{C}-78^{\circ} \mathrm{C}\right)$, on cooling down from the uniaxial $\mathrm{Sm}-A$ phase. Measurements are carried out on a $5.5 \mu \mathrm{m}$ homeotropic cell under an in-plane electric field. The various phases are marked on the left and right. The curves for various colors may not all be clear in the Figure. 


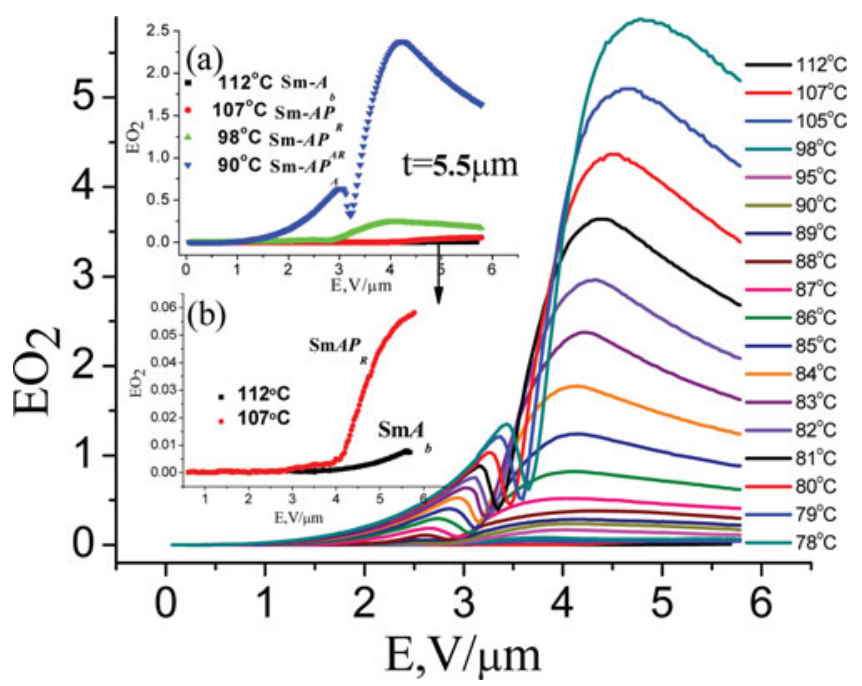

Figure 3. The 2nd harmonic electro-optic response $\left(E \mathrm{O}_{2}\right)$ of orthogonal smectic phases observed in BCLC compound (PAL29) with a reduction in temperature from the isotropic phase. The inset figure (a) shows the $\mathrm{Sm}-A_{b}$ at $112^{\circ} \mathrm{C}(\mathbf{\square}), \mathrm{Sm}-A P_{R}$ at $107^{\circ} \mathrm{C}\left({ }^{\circ} \mathrm{C}\right.$;), Sm- $A P_{A R}$ at $98^{\circ} \mathrm{C}\left({ }^{\circ} 73\right.$; ) and $\mathrm{Sm}-A P_{A}$ at $90^{\circ} \mathrm{C}(\mathbf{\nabla})$. The inset figure (b) shows the $E O_{2}$ response only in $\mathrm{Sm}-A_{b}$ phase at $112^{\circ} \mathrm{C}(\mathbf{\square})$ and red filled circle SmAPR.

\subsection{Second Harmonic Electro-optic Response}

The second harmonic electro-optic response $\left(\mathrm{EO}_{2}\right)$ was recorded [23] by applying a squarewave ac voltage at a $f=80 \mathrm{~Hz}$ across the in-plane electrodes having electrode distance $\sim 80 \mu \mathrm{m}$. The magnitude of $E O_{2}$ response is proportional to the $\sin ^{2} \theta$, where, $\theta=\pi \delta n d / \lambda$. If $\theta<<1$, the linear dependence of $\delta n(\boldsymbol{E})$ on $\boldsymbol{E}$ would give a quadratic dependence of $E \mathrm{O}_{2}$ on $\boldsymbol{E}$ (i.e., $E \mathrm{O}_{2} \alpha \boldsymbol{E}^{2}$ ) due to $\mathrm{EO} 2 \alpha \theta^{2}$. Figure 3 shows the temperature dependent $E O 2$ response while the sample is cooled from the $\operatorname{Sm} A$ phase.

The plot in Fig. 3 reveals the presence of all orthogonal phases $\left(\mathrm{Sm}-A_{b}, \mathrm{Sm}-A P_{R}, \mathrm{Sm}-\right.$ $A P_{A R}$ and $\left.\mathrm{Sm}-A P_{A}\right)$ and it is in good agreement with the biaxiality measurement results. The inset figure (a) of Fig. 3 shows the phases Sm- $A_{b}$ at $112^{\circ} \mathrm{C}, \mathrm{Sm}-A P_{R}$, at $107^{\circ} \mathrm{C} \mathrm{Sm}-A P_{A R}$ at $98^{\circ} \mathrm{C}$ and $\mathrm{Sm}-A P_{A}$ at $90^{\circ} \mathrm{C}$. As the magnitude of $E O 2$ response is very small for Sm- $A_{b}$ and $\mathrm{Sm}-A P_{R}$ when compared to the other Sm- $A P_{A R}$ and $\mathrm{Sm}-A P_{A}$ phases, the field dependent $E O 2$ response of both $\mathrm{Sm}-A_{b}$ and $\mathrm{Sm}-A P_{R}$ are repeated on an extended scale separately in inset figure (b) of Fig. 3. The EO2 response from the material under study is fitted to the equation $E O_{2}=k \cdot E^{\gamma}$ to determine the exponent $\gamma$. In Sm- $A_{P R}$ and Sm- $A P_{A R}, \gamma=2$ for the lower values of $\boldsymbol{E}$, which implies the linear dependence of $\delta n(\boldsymbol{E})$ on $\boldsymbol{E}$ due to the polar interaction with $\boldsymbol{E}$. When we consider $\mathrm{Sm}-A P_{A}$ phase, $\gamma$ shows a cross over behavior $(2.5$ to $3.5)$ due to the combination of polar and dielectric interactions. In optically biaxial Sm- $A_{b}$, the fitting result shows $\gamma=4.2$, which assumes that this phase is non-polar in nature.

\subsection{Dielectric Measurements}

The dielectric relaxation measurement over a frequency range $1 \mathrm{~Hz}$ to $1 \mathrm{MHz}$ was performed in a homogeneous cell having $7.3 \mu \mathrm{m}$ thickness. Low resistance $(20 \Omega / \mathbf{\square})$ indium tin oxide (ITO) glass substrates were used to make cells for the study. The measurement was carried 


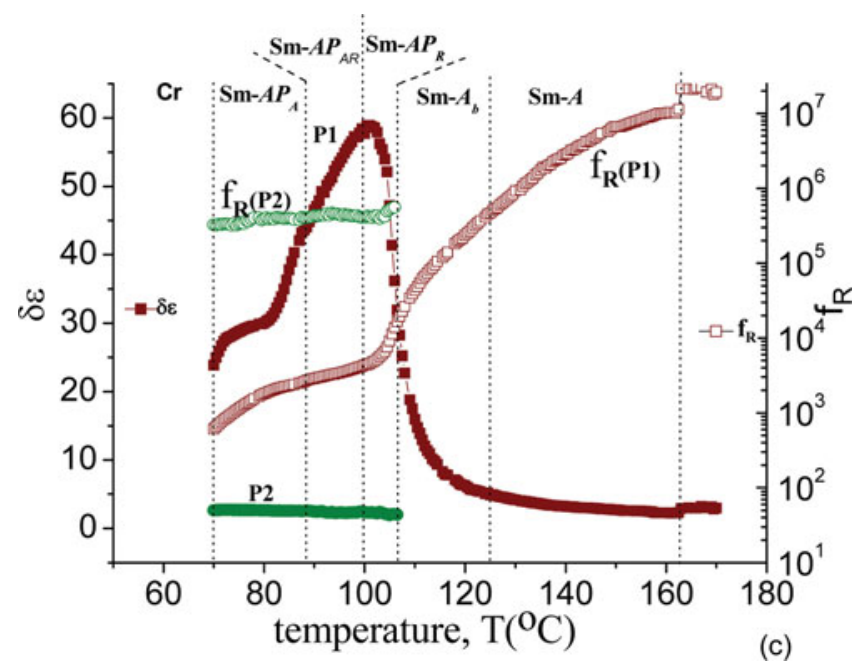

Figure 4. Dielectric relaxation strength $(\delta \varepsilon)$ and the relaxation frequency $\left(f_{R}\right)$ as a function of temperature measured in a planar cell configuration.

out over a temperature range of $170^{\circ} \mathrm{C}-70^{\circ} \mathrm{C}$ (varied in steps of $0.5^{\circ} \mathrm{C}$ ) and the dielectric spectrum is fitted to the Havriliak-Negami equation,

$$
\varepsilon^{*}(\omega)=\varepsilon^{\prime}-i \varepsilon^{\prime \prime}=\varepsilon_{\infty}+\sum_{j=1}^{n} \frac{\delta \varepsilon_{i}}{\left[1+\left(i \omega \tau_{j}\right)^{\alpha_{i}}\right]^{\beta_{i}}}-\frac{i \sigma_{d c}}{\varepsilon_{0} \omega}
$$

where, $\varepsilon_{\infty}$ is the high frequency dielectric permittivity, $j$ varying from 1 to n (number of relaxation process), $\omega$ is the angular frequency, $\varepsilon_{0}$ is the permittivity in free space, $\iota_{j}$ is the relaxation time of the $j^{\text {th }}$ relaxation process, $\delta \varepsilon_{j}$ is the dielectric relaxation strength and $\alpha_{j}$ and $\beta_{j}$ are the symmetric and asymmetric broadening parameters of the $j^{\text {th }}$ process. The fitting parameters of the dominant process, e.g. dielectric strength, $\delta \varepsilon$ (amplitude) and the relaxation frequency, $f_{R}$ are shown in Fig. 4 (see [26]).

While cooling down from the isotropic phase, the relaxation processes, $\mathrm{P} 1$ is moving towards the lower frequency part. In polar phases, the high frequency relaxation mode is due to the non collective motion of polar molecules and the low frequency relaxation mode is due to the collective movement of dipole moments. It is clearly seen in Fig. 4 that, the dielectric amplitude $\Delta \varepsilon$ increases with a reduction in temperature and reaches maximum at the $\mathrm{Sm}-A P_{R}$ to $\mathrm{Sm}-A P_{A R}$ phase transition.

\section{Conclusions and Perspectives}

In summary, the occurrence of five different orthogonal smectic phases (Sm- $A, \mathrm{Sm}-A_{b}, \mathrm{Sm}$ $A P_{R}, \mathrm{Sm}-A P_{A R}$, and $\left.\mathrm{Sm}-A P_{A}\right)$ by field dependent biaxiality measurements were confirmed by the second harmonic electro-optic response and the dielectric spectroscopy. The Sm- $A_{b}$ phase exhibits very small values of biaxiality when compared to all other orthogonal smectic phases observed. Biaxiality measurement results are in agreement with the second harmonic electro-optic response measurement results. The dielectric study reveals an increasing trend of dielectric amplitude with a reduction in temperature and it reaches the summit at $\mathrm{Sm}-A P_{R}$ to $\mathrm{Sm}-A P_{A R}$ phase transition region. 


\section{Funding}

We thank the Science Foundation of Ireland for the grant 13/US/I2866 under IrelandUS co-operative research program and by US-Ireland R\&D Partnership Program jointly administrated with the United States NSF (NSFDMR-1410649).

\section{References}

[1] De Gennes, P. G. \& Prost, J. (1993). The Physics of Liquid Crystals, Clarendon: Oxford.

[2] Chandrasekhar, S. (1992). Liquid Crystals, Cambridge: Cambridge University Press.

[3] Brand, H. R., Cladis, P. E., \& Pleiner, H. (1992). Macromolecules, 25, 7223.

[4] Brand, H. R., Cladis, P. E., \& Pleiner, H. (1998). Eur. Phys. J. B, 6, 347.

[5] Niori, T., Sekine, T., Watanabe, J., Furukawa, T., \& Takezoe, H. (1996). J. Mater. Chem., 6, 1231.

[6] Takezoe, H., \& Takanishi, Y. (2006). Jpn. J. Appl. Phys., 45, 597.

[7] Reddy, R. A., \& Tschierske, C. (2006). J. Mater. Chem., 16, 907.

[8] Walba, D. M., Korblova, E., Shao, R., Maclennan, J.E., Link, D. R., Glaser M. A., \& Clark, N. A. (2000). Science, 288, 2181.

[9] Lubensky, T. C. (2000). Science, 288, 2146.

[10] Eremin, A., Diele, S., Pelzl, G., Nadasi, H., Weissflog, W., Salfetnikova, J., \& Kresse, H. (2001). Phys. Rev. E, 64, 051707.

[11] Sadashiva, B. K., Reddy, R. A., Pratibha R., \& Madhusudana, N. V. (2002). J. Mater. Chem., $12,943$.

[12] Schröder, M. W., Diele, S., Pancenko, N., Weissflog, W., \& Pelzl, G. (2002). J. Mater. Chem., $12,1331$.

[13] Murthy, H. N. S., \& Sadashiva, B. K. (2004). Liq. Cryst., 31, 567.

[14] Pociecha, D., Cepic, M., Gorecka, E., \& Mieczkowski, J., (2003). Phys. Rev. Lett., 91, 185501.

[15] Shimbo, Y., Gorecka, E., Pociecha, D., Araoka, F., Goto, M., Takanishi, Y., Ishikawa, K., Meieczkowski, J., Gomola, K., \& Takezoe, H. (2006). Phys. Rev. Lett., 97, 113901.

[16] Gomola, K., Guo, L., Pociecha, D., Araoka, F., Ishikawa, K., \& Takezoe, H. (2010). J. Mater. Chem., 20, 7944.

[17] Reddy, R. A., Zhu, Ch., Shao, R., Korblova, E., Gong, T., Shen, Yo., Garcia, E., Glaser, M. A., Maclennan, J. E., Walba, D. M., \& Clark, N. A. (2011). Science, 332, 72.

[18] Nair, G. G., Bailey, C. A., Taushanoff, S., Csorba, K. F., Vajda, A., Varga, Z., Bota A., \& Jakli, A. (2008). Adv. Mater., 20, 3138.

[19] Pratibha, R., Madhusudana N. V., \& Sadashiva, B. K. (2000). Science, 288, 2184.

[20] Nagaraj, M., Panarin, Yu. P., Manna, U., Vij, J. K., Keith, C., \& Tschierske, C. (2010). Appl. Phys. Lett., 97, 213505.

[21] Panarin, Yu. P., Nagaraj, M., Vij, J. K., Keith, C., \& Tschierske, C., (2010). Euro Phys. Lett., 92, 26002.

[22] Sreenilayam, S., Panarin, Yu. P., Vij, J. K., Osipov, M., Lehmann, A., \& Tschierske, C. (2013). Phys. Rev. E, 88, 012504.

[23] Panarin, Yu. P., Nagaraj, M., Sreenilayam, S., Vij, J. K., Lehmann, A., \& Tschierske, C. (2011). Phys. Rev. Lett., 107, 247801.

[24] Nagaraj, M., Sreenilayam, S. P., Panarin, Yu. P., Vij, J. K., Keith C., \& Tschierske, C. (2011). Mol. Cryst. Liq. Cryst., 540, 82.

[25] Nagaraj, M., Panarin, Yu. P., Manna, U., Vij, J. K., Keith, C., \& Tschierske, C. (2010). Appl. Phys. Lett., 96, 011106.

[26] Panarin, Y. P., Xu, H., MacLudgha, S. T., \& Vij, J. K. (1994). Jap. J. Appl. Phys. Part 1, 33, 2648. 